\title{
REVITALISASI NILAI-NILAI AGAMA DAN KEARIFAN LOKAL DALAM GERAKAN PENYELAMATAN DAN KELESTARIAN SUMBER DAYA ALAM SALINGKA DANAU MANINJAU SUMATERA BARAT
}

\author{
Jamaldi \\ Fakultas Ushuluddin Universitas Islam Negeri (UIN) Imam Bonjol Padang \\ e-mail:jamaldi70@gmail.com \\ DOI: http:/ / dx.doi.org/10.30983/islam_realitas.v3i2.400
}

Diterima: 07 November $2017 \quad$ Direvisi:29 November $2017 \quad$ Diterbitkan: 31 Desember 2017

\begin{abstract}
Maninjau Lake which is one of the attractions in Agam Regency has been known in the world of tourism to the international level. The beauty of the lake along with twist 44 and guarded row of rows of rows, adding charm to the beauty of the lake. But lately various problems that occur related to the real condition or the beauty of the lake began to be neglected. Currently the condition of the lake is polluted in very poor condition. $V$ arious efforts have been made from the issuance of regulations, reduction efforts and community involvement in the saving of the lake. One important element is the value of religious beliefs as well as the local wisdom of the community such as the religious principles adopted, cultural values, tambos, history and traditions of the hereditary is the social capital and potential of hidden communities that need to be considered in development programs including the lake lake environmental pollution rescue movement. This effort can be done through, implementing, actualizing and revitalizing religious and cultural values which are summarized in the local wisdom of Maninjau Lake communities in solving environmental pollution problems of the lake in particular and environmental issues in general
\end{abstract}

Keywords: Revitalization, Religion and Local Wisdom, Rescue Movement and Lake Conservation

\section{Abstrak}

Danau Maninjau yang merupakan salah satu objek wisata di Kabupaten Agam sudah dikenal dalam dunia pariwisata sampai ke tingkat internasional. Keindahan danau diserta kelok 44 dan dijaga deretan bukit barisan, menambah pesona keelokan danau. Namun belakangan ini berbagai permasalahan terjadi terkait kondisi nyata atau keasrian danau yang mulai terabaikan. Saat ini kondisi danau tercemar dalam kondisi yang sangat memprihatinkan. Berbagai upaya telah dilakukan mulai dari penerbitan peraturan, upaya pengurangan, dan pelibatan masyarakat dalam penyelematan danau. Salah satu unsur penting adalah nilai keyakinan agama serta kearifan lokal masyarakat seperti prinsip agama yang dianut, nilai budaya, tambo, sejarah dan tradisi turun temurun merupakan modal sosial dan potensi masyarakat terpendam yang perlu dipertimbangkan dalam program pembangunan termasuk gerakan penyelamatan pencemaran lingkungan danau. Upaya ini dapat dilakukan melalui penerapan, aktualisasi, dan perevitalisasian nilai agama dan budaya yang terangkum dalam kearifan lokal masyarakat salingka Danau Maninjau dalam memecahkan persoalan pencemaran lingkungan danau khususnya dan persoalan lingkungan pada umumnya

Kata Kunci: Revitalisasi, Agama dan Kearifan Lokal, Gerakan Penyelamatan dan Pelestarian Danau

\section{Latar Belakang}

Manusia dalam kehidupan sehari-hari mempunyai ketergantungan yang sangat erat dengan lingkungannya. Seperti makhluk hidup lainnya, manusia berinteraksi dan dipengaruhi bahkan mempengaruhi lingkungan. Manakala terjadi perubahan pada sifat lingkungan hidup

yang berada di luar batas kemampuan adaptasi manusia, baik perubahan secara alamiah maupun perubahan yang disebabkan oleh aktivitas hidupnya, kelangsungan hidup akan 
terancam ${ }^{1}$. Konsekuensi dari perubahan itu mengakibatkan hubungan manusia dengan lingkungan berjalan tidak sehat, situasi inilah yang lebih dikenal dengan istilah krisis lingkungan hidup yang sekarang menjadi isu global.

Berbagai krisis lingkungan hidup yang terjadi sekarang ini, baik dalam lingkup global maupun nasional, sebagian besar disebabkan ulah tangan manusia. Pencemaran dan kerusakan lingkungan yang terjadi di laut, hutan, atmosfir, air ataupun lainnya, pada dasarnya bersumber pada perilaku manusia yang tidak bertanggung jawab dan tidak memiliki kepedulian, atau hanya mementingkan diri sendiri. 2 Kondisi lingkungan hidup dewasa ini begitu memprihatinkan, bahkan sampai pada titik nadir yang mengenaskan. global warming (pemanasan global), misalnya, meskipun genderang perang terhadap perilaku kerusakan lingkungan sudah ditabuh dengan keras sejak UN Conference on Human Environment di Stackholm, Swedia, tahun 1972. Namun hingga World Summit on Sustainable Development di Johannesburg Afrika Selatan (2002), bahkan hingga penyelenggaraan konferensi PBB untuk Perubahan Iklim (United Nation For Climate Change Conference, UNFCC) di Bali (tanggal 314 Desember 2007), krisis lingkungan bukan semakin berkurang, malah sebaliknya. ${ }^{3}$ Pada sisi lain, menjamurnya berbagai organisasi sipil yang mencoba memperjuangkan kepentingan lingkungan ternyata juga tidak bisa menekan laju degradasi lingkungan. ${ }^{4}$ Sebaliknya, perilaku destruktif dan eksploitatif, demi meraup

${ }^{1}$ Ottoe Soemarwoto, Analisis Dampak Lingkungan (Yogyakarta: Gajah Mada University Press, 2003), h, 18.

2 Sonny Keraf, Etika Lingkungan (Jakarta: Kompas, 2002), h. xiii.

3 Emil Salim, "Kepemimpinan Lingkungan" dalam Arif Budimanta dkk, Enviromental Leadership (Jakarta: ICDS, 2005), h. vii.

4 Lihat Rahmat Witoelar, "Kepemimpinan Lingkungan untuk Masa Depan Berkelanjutan", dalam Arif Budimanta dkk, Enviromental....,h. iii. kepentingan pribadi, semakin sulit dikendalikan.

Di antara kawasan yang paling rentan terhadap kerusakan dan pencemaran lingkungan adalah kawasan danau. Berdasarkan catatan dan temuan dalam seminar Nasional Limnologi VI Tahun 2012, di antara kerusakan lingkungan danau di Indonesia adalah erosi, sedimentasi dan pendangkalan akibat kerusakan lahan, pencemaran air akibat limbah domestik, dan pertanian maupun pertambangan, kerusakan sumber daya ikan endemik akibat penangkapan (overfishing) maupun budidaya Keramba Jaring Apung (KJA) yang merusak, pertumbuhan gulma air (eceng gondok, hidrilla dsb), bencana banjir dan kekeringan serta bencana arus balik gas sulfida yang terangkat ${ }^{5}$.

Danau Maninjau yang merupakan salah satu objek wisata di Kabupaten Agam sudah dikenal dalam dunia pariwisata sampai ke tingkat internasional. Keindahan danau disertai kelok 44 dan dijaga deretan bukit barisan, menambah pesona keelokan danau. Namun belakangan ini berbagai permasalahan yang terjadi terkait kondisi nyata atau keasrian danau yang mulai terabaikan. Berbagai aktivitas penduduk yang ada di sempadan danau Maninjau, seperti permukiman, perhotelan, pertanian dan peternakan merupakan sumber bahan pencemar yang masuk ke perairan danau. Kegiatan yang umumnya di bagian badan perairan danau, berupa pembudidayaan ikan dengan teknik keramba jaring apung (KJA) juga merupakan sumber limbah yang potensial mencemari perairan danau. Saat ini kegiatan perikanan KJA sudah melampaui daya dukung perairan danau. kegiatan budidaya perikanan dengan teknik KJA selalu mengalami peningkatan setiap tahunnya. Sampai akhir tahun 2006 saja,

5 Tim Penyusun, Profil 15 Danau Prioritas Nasional, (Jakarta: Kementerian Lingkungan Hidup RI, 2011), h. 24 
terdapat 8.955 unit KJA yang beroperasi di perairan Danau Maninjau 6 . Bahkan pada tahun 2015 jumlah karamba meningkat tajam sudah sangat melebihi kapasitas yaitu 23.000 unit KJA dari batas toleransi 6.000 unit $\mathrm{KJA}^{7}$.

Menggerakkan partisipasi masyarakat membutuhkan upaya komprehensif penyelamatan Danau Maninjau khususnya yang perlu dilakukan oleh semua pihak mulai dari pihak pemerintah sebagai pengambil kebijakan, para penggiat dan pemerhati seperti perguruan tinggi, LSM lingkungan dan lembaga riset baik pemerintahan maupun swasta. Satu unsur masyarakat lokal yang tidak boleh dilupakan dan sangat menentukan jalannya partisipasi masyarakat yaitu dengan memperhatikan keunikan nilai agama dan kearifan lokal yang mereka anut. Nilai-nilai tersebut juga sangat menentukan kesuksesan upaya menggerakkan partisipasi masyarakat dalam program penyelamatan danau secara khusus dan penyelamatan lingkungan dan sumber daya alam secara umum.

Dengan demikian, nilai keyakinan agama serta kearifan lokal masyarakat seperti prinsip agama yang dianut, nilai budaya, tambo, sejarah dan tradisi turun temurun merupakan modal sosial dan potensi masyarakat terpendam yang perlu dipertimbangkan dalam program pembangunan termasuk gerakan penyelamatan pencemaran lingkungan danau. Upaya ini dapat dilakukan melalui, penerapan, aktualisasi dan merevitalisasi nilai agama dan budaya yang terangkum dalam kearifan lokal masyarakat salingka Danau Maninjau dalam memecahkan persoalan pencemaran lingkungan danau khususnya dan persoalan lingkungan pada umumnya. Jadi penelitian ini akan

${ }^{6}$ Tim Redaksi, "Untuk Penyelamatan Danau Maninjau, Ada Tiga Indikator Yang Harus Dilakukan" diakses dari www.agammediacenter. co.id. pada tanggal 15 April 2016.

${ }^{7}$ Tim Padang Ekspres, "Penyelamatan Danau Maninjau Dimulai Penyelamatan Danau Maninjau Dimulai”, Padang Ekspres 18 Maret 2016. mengungkap revitalisasi nilai-nilai keagamaan dan kearifan lokal masyarakat salingka Danau Maninjau dalam penyelematan dan kelestarian sumber daya alam Danau Maninjau.

Mengacu kepada persoalan yang diuraikan di atas, maka rumusan masalah penelitian ini adalah bagaimana upaya revitalisasi nilai nilai agama dan kearifan lokal masyarakat salingka Danau Maninjau dalam gerakan penyelamatan dan kelestarian sumber daya alam Danau Maninjau. Adapun batasan penelitian ini akan mengungkap tentang: Bagaimana upaya revitalisasi nilai keagamaan dan kearifan lokal dalam upaya gerakan penyelamatan Danau Maninjau.

Di samping itu, penelitian ini diharapkan bermanfaat secara praktis kepada pihak-pihak terkait, yakni; 1) Masyarakat salingka Danau Maninjau untuk menyelesaikan persoalan pencemaran lingkungan danau yang semakin mengkhawatirkan dengan menumbuhkan kepedulian dan partisipatif untuk mengungkap nilai keyakinan agama dan kearifan lokal yang mereka anut selama ini; 2) Pemerintah Kabupaten Agam sebagai penanggung jawab program penyelamatan Danau Maninjau sebagai perpanjangan tangan pemerintah pusat. Dengan adanya penelitian ini akan memberi solusi alternatif setidaknya mendukung program pemerintah dalam hal penguatan partisipasi masyarakat dalam penyelamatan Danau Maninjau; 3) Tokoh agama dan tokoh adat masyarakat salingka Danau Maninjau sebagai penguatan peran dan menggali potensi mereka dalam memecahkan persoalan lingkungan sekitar mereka.

Penelitian ini akan menggunakan metode kualitatif dengan pendekatan etnografi, objek yang diteliti secara natural, dalam keadaan yang alami. Pengumpulan data akan dilakukan secara berulang-ulang agar mendapat informasi dengan benar dan mendalam sehingga dapat menghayati meaning atau arti tingkah laku. Studi etnografi 
dilakukan dengan menyelami keunikankeunikan peran dan tingkah laku, keunikan pengalaman-pengalaman manusia dalam mendefinisikan, menafsirkan dan mengkontruksi dunianya

Spradley menjelaskan bahwa penelitian yang menggunakan metode kualitatif lebih tepat digunakan pada penelitian tentang perilaku atau budaya pada suatu situasi sosial ${ }^{8}$. Pendekatan ini menurut Guba menganut paradigma yang berurusan dengan pemahaman terhadap penemuan gejala-gejala dalam suatu realitas konteks sosialnya ${ }^{9}$.

Dalam penelitian tentang revitalisasi nilai-nilai agama dan kearifan lokal dalam gerakan penyelamatan Danau Maninjau ini, peneliti mengungkap secara emik, sebagai upaya pelibatan langsung peneliti ke dalam objek penelitian. Pendekatan emik merupakan esensi yang sahih untuk fenomena sosial pada suatu waktu tertentu. Pendekatan ini relevan sebagai usaha untuk mengungkap nilai keyakinan, pola dan kearifan lokal masyarakat menurut persepsi pemilik budaya. Pendekatan emik menegaskan bahwa makna sosial dan budaya dari orang dalam, karena emik berkaitan dengan keseluruhan unsur sosial dan budaya $^{10}$.

Objek dalam penelitian ini masyarakat nagari, ninik mamak, alim ulama, bundo kanduang dan masyarakat luas berupa peran dan partisipasi mereka dalam penyelamatan lingkungan danau Maninjau. Disamping itu dikaitkan pula peran tokoh-tokoh masyarakat, tokoh adat, yang mengetahui banyak tentang persoalan masyarakat yang berkembang di nagari-nagari tersebut.

8 James, P Spredley, Metodologi Etnografi, diterjemahkan oleh M.Zulfa Elizabeth, judul asli, The Etnographic Interview (Yogyakarta: PT Tiara Wacana Yogya, 1997), h. 35.

${ }^{9} Y v o n n a$ S. Lincoln dan E.G Guba., Naturalistic Inquiry (London: Sage Publication 1985), h. 23.

10 Suwardi Endraswara, Metodologi Penelitian Kebudayaan (Yogyakarta: Gadjah Mada University Press, 2006), h. 35
Dengan mempergunakan pendekatan emik, peneliti mempersiapkan diri untuk terlibat langsung dalam seluruh peristiwa sosial masyarakat, baik dalam konteks di luar maupun di dalam konteks ruang. Lebih dalam lagi, peneliti memasuki wilayah masyarakat untuk menemukan respon atas aksi reaksi atau relasi yang terbangun melalui peristiwa sosial. Artinya, baik pada saat peneliti sedang berada di wilayah tradisi maupun di tengah-tengah masyarakat, peneliti melibatkan diri secara penuh dengan tujuan penghilangan jarak agar peneliti menemukan seluas-luas dan selengkap-lengkapnya informasi sebagai data. Dengan kata lain, tradisi dan kebiasaan dengan seluruh permasalahan di dalamnya, peneliti melihat, mendengar, memikirkan, hingga merasakannya tanpa jarak. Peneliti berada di dalam keseluruhan tradisi dengan berbagai dinamika yang terjadi di dalamnya.

Data dalam penelitian ini diperoleh melalui dua jenis sumber, yakni sumber data primer dan sekunder. Informan yang terdiri dari masyarakat adat dan budaya lokal yang dipilih secara bergulir atau snowball sampling, pihak pemerintah sebagai pemegang kebijakan dalam isu-isu lingkungan dan tokoh agama/penjaga moral, dan tokoh adat merupakan kategori sumber data primer. Sedangkan data sekunder ditemukan dari tulisan dan pendapat para pakar dan ahli di luar masyarakat objek penelitian. Dengan demikian, jenis data penelitian ini berupa katakata, kalimat, tindakan, dan peristiwa.

Menurut Lofland dalam Moleong, sumber data utama dalam penelitian kualitatif ialah kata-kata dan tindakan, selebihnya adalah data tambahan seperti dokumen dan lain-lain ${ }^{11}$. Dengan begitu, jenis data yang ada dalam penelitian ini adalah data kualitatif. Data diperoleh dari hasil wawancara dengan informan yang dilakukan secara mendalam

${ }^{11}$ Lexy J Moleong, Metode Penelitian Kualitatif (Bandung: PT. Rosdakarya, 2009), h.157. 
untuk mengetahui persepsi, sikap, pandangan, dan gagasan para informan terhadap nilai agama dan kearifan lokal partisipasi masyarakat. Di samping itu, demi tercapainya kelengkapan penelitian, data juga diperoleh melalui observasi dan dokumen lain yang berkaitan secara langsung maupun tidak langsung dengan objek penelitian. Untuk memperoleh hasil penelitian yang memadai dan komprehensif, penelitian ini juga membutuhkan data yang bersifat kuantitatif, yang befungsi sebagai penguat, terutama pada saat diperlukan analisis terhadap data yang bersifat statistik, bagan, diagram, dan hal lain yang sejenis. Data penunjang ini, misalnya, dibutuhkan pada saat menganalisis tingkat perkembangan objek penelitian dan seberapa besar pengaruh objek penelitian kepada masyarakat sebagai objek penelitian.

Penelitian ini akan berpedoman pada dua belas (12\} langkah penelitian kualitatif model Spradley (1980) yang dimodifikasi menjadi sembilan (9) langkah: (1) menentukan situasi sosial, (2) melakukan observasi lapangan, (3) melakukan analisis kawasan, (4) melakukan observasi terfokus, (5) melakukan analisis taksonomi, (6) melakukan analisis terseleksi, (7) melakukan observasi terseleksi, (melakukan analisis komponensial), melakukan analisis tema budaya, (9) menulis laporan penelitian. ${ }^{12}$

\section{Penelitian Relevan}

Isu lingkungan tentang pencemaran dan kerusakan ekosistem danau-danau di Indonesia akibat eksploitasi telah menjadi persoalan nasional. Banyak program dan kajian mengarah pada upaya penyelamatan lingkungan dan ekosistem danau-danau ini. Secara umum penelitian tentang managemen pengelolaan program nasional penyelamatan danau telah dilakukan oleh Tri Retnaningsih Soeprobowati (2015), Integrated Lake Basin

12James P. Spredley, Metodologi Etnografi..., h. 23.
Management For Save Indonesian Lake Movement. Tri lebih terfokus pada program penyelamatan Danau Rawapening, terpilih sebagai proyek percontohan untuk Gerakan Penyelamatan Danau $=$ GERMADAN). Pada dasarnya tidak ada perbedaan antara Integrated Lake Basin Management (ILBM) dan GERMADAN. Teknologi pendekatan dan pengetahuan informasi dari ILBM terkait ke dalam aplikasi ilmu pengetahuan dan teknologi untuk danau perbaikan di GERMADAN. Pilar institusi, kebijakan, dan keuangan dari ILBM adalah menjadi tata pemerintahan yang baik di GERMADAN, sedangkan partisipasi dalam ILBM adalah berkembang menjadi pemberdayaan masyarakat di GERMADAN. ${ }^{13}$

Khusus studi di Danau Maninjau terdapat pada penelitian Triyanto, Lukman dan Ami A. Meutia (2005), Induksi Keramba Jaring Apung Berlapis sebagai Alternatif Sistem Pemeliharaan Ikan dalam Keramba Ramah Lingkungan di Danau Maninjau Sumatera Barat, dan Lukman, 2011, Pengembangan Karamba Jaring Apung Pertimbangan Dayadukung Dan Ancamannya Terhadap Lingkungan Perairan Danau Maninjau Sumatera Barat. Secara umum 2 peneliti LIPI ini secara berkala melakukan penelitian dampak KJA terhadap lingkungan. Walaupun beda tahun kedua studi ini menemukan bahwa aktivitas KJA yang melebihi kapasitas sangat merusak air dan mengakibatka pencemaran lingkungan ${ }^{14}$.

Adapun studi tentang kearifan lokal dan penyelamatan lingkungan telah banyak

13 Tri Retnaningsih Soeprobowati, "Integrated Lake Basin Management For Save Indonesian Lake Movement", Procedia Environmental Sciences, Vol. 23 (2015), h. 368-374.

14 Triyanto, Lukman dan Ami A. Meutia, "Induksi Keramba Jaring Apung Berlapis sebagai Alternatif Sistem Pemeliharaan Ikan dalam Keramba Ramah Lingkungan di Danau Maninjau Sumatera Barat", Jurnal Limnotek LIPI edisi 2 2005, h. 24-37. Lukman, "Pengembangan Karamba Jaring Apung Pertimbangan Daya Dukung dan Ancamannya terhadap Lingkungan Perairan Danau Maninjau Sumatera Barat", Jurnal Limnotek LIPI edisi 2 2011, 124-137. 
dilakukan di antaranya: Ira Indrawardana (2012), Kearifan Lokal Adat Masyarakat Sunda dalam Hubungan dengan Lingkungan Alam, Penelitian ini menghasilkan temuan bahwa pada dasarnya kearifan lokal masyarakat Sunda Kanekes disarikan dari pengalaman masyarakat Sunda lama yang sangat akrab dengan lingkungannya dan sudah lama hidup dalam budaya masyarakat peladang. Kearifan lokal adat, suatu kondisi sosial dan budaya yang didalamnya terkandung khasanah nilai-nilai budaya yang menghargai dan adaptif dengan alam sekitar, dan tertata secara ajeg dalam suatu tatanan adat istiadat suatu masyarakat. ${ }^{15}$

Arry Retnowati (2014), Environmental Ethics in Local Knowledge Responding to Climate Change: An Understanding of Seasonal Traditional Calendar Pranoto Mongso and Its Phenology in Karst Area of GunungKidul, Yogyakarta, Indonesia. Penelitian ini menjelaskan hubungan sifat manusia, proses tata ruang sosial tertanam sebagai etika lingkungan di tingkat masyarakat petani di wilayah Gunung Kidul, Selatan Jawa, dapat bertahan hidup, dan mengatasi musim kemarau karena kelangkaan air. Cara mereka menghargai dan mengatasi lingkungan dieksplorasi melalui observasi lapangan dan pemahaman partisipatif pengetahuan lokal yang disebut Pranoto Mongso sebuah kalender musiman tradisional ${ }^{16}$.

Vincentia Reni Vitasurya, 2016, Local Wisdom for Sustainable Development of Rural Tourism, Case on Kalibiru and Lopati Village, Province of Daerah Istimewa Yogyakarta. Penelitian ini dilakukan di desa wisata Kalibiru dan Lopati untuk mengetahui kesadaran

15 Ira Indrawardana, "Kearifan Lokal Adat Masyarakat Sunda dalam Hubungan Dengan Lingkungan Alam", Komunitas, Vol. 4, No. 1, 2012, h. 18.

16 Arry Retnowati, "Environmental Ethics in Local Knowledge Responding to Climate Change: An Understanding of Seasonal Traditional Calendar Pranoto Mongso and Its Phenology in Karst Area of Gunung Kidul, Yogyakarta, Indonesia”, Procedia Environmental Sciences, Vol. 20 , 2014, h. 785-794. masyarakat tentang kearifan lokal untuk menjaga lingkungan pedesaan yang berbasis wisata. Penelitian ini menggunakan partisipasi masyarakat untuk memperoleh data berdasarkan motivasi masyarakat. Pengamatan oleh pemetaan dan wawancara dilakukan untuk mengukur aspek pelestarian lingkungan. Hasilnya diharapkan menjadi model konservasi desa wisata berbasis alam dengan partisipasi warga karena dapat diimplementasikan untuk pengembangan desa wisata di masa depan ${ }^{17}$.

Sumarmi (2015), Local Wisdom of Osing People in Conserving Water Resources, Masingmasing suku di Indonesia memiliki kearifan lokal tertentu untuk melestarikan lingkungan mereka, termasuk kearifan untuk mengelola sumber daya air. Kearifan lokal masyarakat Osing dalam mengelola sumber daya air meliputi pengetahuan, nilai-nilai, moral dan etika, dan norma-norma yang diterapkan dalam bentuk saran, aturan dan sanksi, serta kata-kata bijak sebagai pedoman bagi mereka untuk bersikap dan bertindak dalam menjaga, menjaga dan melestarikan mata air Mbah Buyut Citi. Untuk menjaga aliran konstan debit air, mereka melindungi pohon-pohon dan tanaman di sekitar musim semi (belik), baik belik lanang dan wadon belik. ${ }^{18}$.

Mukhtar (2010), Pengelolaan Program Hutan Kemasyarakatan Berbasis Kearifan Lokal :Studi Kasus di Kawasan Hutan Lindung Sesaot Lombok Barat. Penelitian ini mengungkap bahwa terjadi perbedaan pemahaman antara masyarakat dengan Dinas Kehutanan. Masyarakat memaknai konservasi dari keseluruhan vegetasi sebagai kesatuan fungsi

${ }^{17}$ Vincentia Reni Vitasurya, "Local Wisdom for Sustainable Development of Rural Tourism, Case on Kalibiru and Lopati Village, Province of Daerah Istimewa Yogyakarta". Procedia - Social and Behavioral Sciences, Vol. 21, 2016, h. 97-108.

${ }^{18}$ Sumarmi, "Local Wisdom of Osing People in Conserving Water Resources", Jurnal Komunitas, Vol. 7, No. 1, 2015, h. 43-51. 
ekonomi dan konservasi, sehingga pemanfaatan lahan lebih didominasi oleh tanaman MPTS. Dinas Kehutanan memaknai tanaman pohon untuk pengintegrasian fungsi konservasi guna mendukung manfaat ekonomi. Sedangkan revitalisasi nilai Awig-awig sebagai aturan pelaksanaan program $\mathrm{HKm}$ masih dipandang sebagai simbolisasi nilai lokal. Dalam implementasinya belum efektif untuk mendukung pengintegrasian fungsi konservasi dan fungsi ekonomi sesuai dengan tujuan program $\mathrm{HKm}^{19}$.

Penelitian tentang kearifan lokal dan tema-tema lingkungan di atas umumnya meneliti tentang pertanian, hutan lindung dan desa wisata, penulis belum menemukan studi yang lebih terfokus dalam isu lingkungan dalam penyelamatan danau. Sekalipun ada ketika bicara tentang kearifan lokal akan berbeda fenomena di setiap lokasi dan daerah, karena masing-masing budaya mempunyai keunikan dan perbedaan dalam kontens budaya dan persoalan yang mengitarinya.

\section{Kearifan Lokal sebuah Kerangka Teoritik}

Era poskolonial merupakan era baru sejarah dimulainya perspektif kearifan lokal (local wisdom) yang melibatkan sistem pengetahuan dan teknologi lokal dalam pembangunan berkelanjutan di berbagai dunia termasuk Indonesia. Dalam pandangan John Haba sebagaimana dikutip Irwan Abdullah, kearifan lokal mengacu pada berbagai kekayaan budaya yang tumbuh dan berkembang dalam sebuah masyarakat yang dikenal, dipercayai dan diakui sebagai elemenelemen penting yang mampu mempertebal kohesi sosial di antara warga masyarakat ${ }^{20}$.

19 Mukhtar, "Pengelolaan Program Hutan Kemasyarakatan Berbasis Kearifan Lokal: Studi Kasus Di Kawasan Hutan Lindung Sesaot Lombok Barat", $W A C A N A$, Vol. 13 No. 1, 2010, h. 23.

${ }^{20}$ Irwan Abdullah, (ed.al), Agama dan Kearifan Lokal dalam Tantangan Zaman (Yogyakarta: Pustaka Pelajar, 2008), h. 7-8.
Berdasarkan inventarisasi Haba, setidaknya ada enam signifikansi dan fungsi sebuah kearifan lokal. Pertama, sebagai penanda identitas sebuah komunitas. Kedua, elemen perekat (aspek kohesif) lintas warga, lintas agama dan kepercayaan. Ketiga, kearifan lokal tidak bersifat memaksa atau dari atas (topdown), tetapi sebuah unsur kultural yang ada dan hidup dalam masyarakat. Keempat, kearifan lokal memberikan warga kebersamaan bagi sebuah komunitas. Kelima, kearifan lokal akan mengubah pola piker dan hubungan timbak balik individu dan kelompok berdasarkan budaya yang dianutnya. Keenam, kearifan lokal mendorong terbangunnya kebersamaan, apresiasi sekaligus sebuah mekanisme bersama yang tumbuh dan dipercayai bersama dari sebuah komunitas terintegrasi. ${ }^{21}$ Keenam fungsi kearifan lokal ini menegaskan pentingnya pendekatan yang berbasis pada nilai-nilai atau kearifan lokal untuk mengatasi persoalan kemanusiaan, konflik, dan lingkungan.

Di samping itu di temukan istilah lain yang mirip dengan kearifan lokal, yaitu pengetahuan indigenous yaitu pengetahuan penduduk asli yang tinggal di lokasi geografis tertentu, yang mempunyai sistem budaya dan kepercayaan yang berbeda dengan sistem pengetahuan dunia intelektual modern ${ }^{22}$. Menurut Sunaryo dan Joshi (2003), pengetahuan indigenous adalah sekumpulan pengetahuan yang diciptakan oleh sekelompok masyarakat dari generasi ke generasi yang hidup menyatu dan selaras dengan alam. Pengetahuan seperti ini berkembang dalam

${ }^{21}$ Irwan Abdullah, (ed.al), Agama dan Kearifan Lokal dalam Tantangan Zaman......... 9.

${ }^{22}$ Indigenous berarti asli atau pribumi. Kata indigenous dalam pengetahuan indigenous merujuk pada masyarakat indigenous. Banyak pihak yang berkeberatan dengan penggunaan istilah pengetahuan indigenous dan mereka lebih menyukai penggunaan istilah pengetahuan lokal. Bandingkan dengan Hikmat Budiman, (ed.al) Hak Minoritas, Ethnos, Demos dan Batas-batas Multikulturalism (Jakarta: The Interseksi Foundation, 2009), h. xxi-xxvi. 
lingkup lokal, menyesuaikan dengan kondisi dan kebutuhan masyarakat. Pengetahuan ini merupakan hasil kreativitas dan inovasi atau uji coba secara terus-menerus dengan melibatkan masukan internal dan pengaruh eksternal dalam usaha untuk menyesuaikan dengan kondisi baru setempat ${ }^{23}$.

Pengetahuan lokal merupakan konsep yang lebih luas yang merujuk pada pengetahuan yang dimiliki oleh sekelompok orang yang hidup di wilayah tertentu untuk jangka waktu yang lama. Dengan demikian, kata indigenous dalam pengetahuan indigenous lebih merujuk pada sifat tempat, dimana pengetahuan tersebut berkembang secara lokal, bukan pada asli atau tidaknya aktor yang mengembangkan pengetahuan tersebut. Jika kita berpedoman pada konsep terakhir ini, maka pengetahuan indigenous sama dengan pengetahuan lokal dan dalam paparan selanjutnya kedua istilah tersebut berarti sama. Pengetahuan lokal suatu masyarakat petani yang hidup di lingkungan wilayah yang spesifik biasanya diperoleh berdasarkan pengalaman yang diwariskan secara turun-temurun.

\section{Kearifan Lokal Masyarakat Nagari di Minangkabau}

Nagari merupakan kesatuan masyarakat yang otonom dan merupakan negara republik mini yang memuat aturan-aturan yang jelas bagi anggotanya, punya pemerintahan sendiri dan punya aturan adat yang mengatur masyarakatnya. Nagari di Minangkabau telah menjadi unit teritorial tertua yang bersifat otonom. Republik ini terus menguat tanpa terpengaruh oleh perubahan institusi dipusat kerajaan Minangkabau di Pagaruyung

Nagari adalah suatu tempat yang terdiri dari beberapa koto, dimana satu koto dengan koto yang lain mempunyai hubungan yang baik

${ }^{23}$ Sunaryo dan L. Joshi. Peranan Pengetahuan Ekologi Lokal dalam Sistem Agroforestri (Bogor: World Agroforestry Centre (ICRAF) Southeast Asia Regional Office Indonesia, 2003), h. 54. dan mempunyai ikatan satu dengan yang lainnya, tarutama dalam sifat-sifat kebersamaan dan seia sekata (sakato) ${ }^{24}$ Sedangkan menurut nagari adalah kesatuan masyarakat hukum adat dalam daerah provinsi Sumatera Barat yang terdiri dari himpunan beberapa suku yang mempunyai wilayah tertentu batas-batasnya, mempunyai harta kekayaan sendiri, berhak mengatur dan mengurus rumah tangganya dan memilih pimpinan pemerintahannya ${ }^{25}$.

Jadi secara historis nagari di Minangkabau telah mengalami perubahan mulai dari awal terbentuknya nagari tertua di Minangkabau (Pariangan Padang Panjang) sampai pada masyarakat maju sekarang ini. Walaupun telah mengalami perjalanan panjang dan berbagai perubahan. Hai ini mengakibatkan pudarnya nilai-nilai lokal Minangkabau yang demokratis, egalilter, dan melemahnya peran anak nagari dalam pelaksanaan pemerintahan nagari, serta hilangnya kemandirian otonomi nagari.

Sukses tidaknya pelaksanaan

pemerintahan nagari sangat ditentukan oleh semua komponen yang ada dalam nagari, terutama perangkat-perangakat nagari yang terdiri dari penghulu sebagai pengendali adat, malin sebagai alim ulama sebagai penyelesai masalah agama yang akan menghukum anak dan kemenakan yang bersalah melakukan pelanggaran hukum syrak, sedangkan manti bertugas menyelesaikan silang sengketa yang timbul dikalangan anak nagari, dan dubalang bertugas mengamankan nagari bila terjadi huru hara baik berupa keributan maupun peperangan $^{26}$

${ }^{24}$ Dt, Rajo Panghulu, Idrus Hakimy, Rangkaian Adat dan Mustika Adat dan Syara' Minang Kabau (Rosyda Karya. Bandung, 1999), h. 20.

25 Tim Penyusun, Perda No 9 Tabun 2000 (Bukittinggi: CV Merapi, 2001), h. 12.

${ }^{26}$ Amir MS Adat Minang Kabau Pola dan Tujuan Hidup Orang Minang (Jakarta: PT. Mutiara Sumber Widya, 2001), h. 47. 
Adapun persyaratan nagari adalah: basosok bajurami dalam arti nagari harus mempunyai tapal batas yang jelas yang ditentukan melalui musyawarah antar penghulu dengan para penghulu di nagarinagari tetangga, balabuah batapian; nagari mempunyai prasarana jalan lingkungan dan sarana penghubung untuk menunjang perekonomian, batapian tampek mandi melambangkan kebersihan terhadap kesucian lahir dan bathin, barumah batanggo; mempunyai makna tempat tinggal, dan membinan kehidupan, batanggo mempunyai makna tempat memasuki rumah yang telah ditentukan sebagai saran mendidik budi pekerti dan kesopanan, karena menurut adat orang yang memasuki rumah lewat pintu belakang berarti telah melanggar norma-norma kesopanan yang berlaku secara umum. Bakorong bakampung; mengandung arti mempunyai penduduk yang merupakan satu kesatuan bulat senasip sepenanggungan, seadat selembaga, seberat seringan, basawah baladang; sebagai lambang ekionomi masyarakat dan simbol kemakmuran untuk kelangsungan hidup, babalai bamusajid; berarti balai sebagai sarana demokrasi dan musajid sebagai sarana penerangan, bapandam bapakuburan: artinya adanya tempat yang disediakan untuk pemakaman. ${ }^{27}$

Di sini dapat dilihat bahwa syarat-syarat di atas merupakan modal dasar nagari dalam menjalankan sistem pemerintahan, sehingga mampu menjadi nagari yang mandiri dan mempunyai otonomi yang penuh dalam pelaksanaan pemerintahan nagari.

\section{Isu Pencemaran Lingkungan Global}

Istilah lingkungan hidup, dalam Bahasa Inggris disebut dengan environment, dalam bahasa belanda disebut dengan millieu atau

${ }^{27}$ A.A. Nafis, Alam Takambang Jadi Guru (Jakarta: PT Grafiti, 1996), h. 34-40. Bandingkan dengan Mansyur, Sejarab Minang Kabau (Jakarta: Bahtera, 1998), h. 56 . dalam Bahasa Prancis disebut dengan I environment. Lingkungan hidup biasa juga disebut dengan lingkungan hidup manusia (buman environment) atau dalam sehari-hari juga cukup disebut dengan "lingkungan" saja. Unsur-unsur lingkungan hidup itu sendiri biasa nya terdiri dari: manusia, hewan, tumbuhan, dll. Lingkungan hidup merupakan bagian yang mutlak dari kehidupan manusia. Dengan kata lain, lingkungan hidup tidak terlepas dari kehidupan manusia. Menurut Undang-Undang No 32 tahun 2009 tentang Perlindungan dan Pengelolaan Lingkungan Hidup, lingkungan hidup adalah kesatuan ruang dengan semua benda, daya, keadaan, dan makhluk hidup, termasuk manusia dan perilakunya, yang mempengaruhi kelangsungan perikehidupan dan kesejahteraan manusia serta makhluk hidup lain.

Dalam kurun waktu empat dekade terakhir, para ilmuan telah mencatat berbagai kerusakan lingkungan global, yang pada umumnya diakibatkan oleh aktivitas manusia di antaranya: 1) perubahan lingkungan yang bersifat irreversible terhadap komposisi atmosfir sehingga menyebabkan perubahan iklim dunia; 2) kerusakan terhadap ozon strastosferik, akibatnya bertambahnya gangguan terhadap berbagai organisme hidup dari sinar ultraviolet matahari; 3) kehilangan keanekaragaman hayati; 4) makin meluasnya pencemaran udara, sungai dan lautan; serta 5) pengurangan dan penurunan muka air tanah. ${ }^{28}$ Beberapa persoalan lingkungan ini berakibat buruk terhadap manusia sendiri seperti banjir, longsor, kelangkaan sumber air, kerusakan hutan, kerusakan mangrove dan bencana kelaparan.

Kerusakan lingkungan global telah diindikasikan dan dikhawatirkan oleh banyak

28 Johan Iskandar, Ekologi Manusia dan Pembangunan Berkelanjutan (Bandung: Program Studi Magister Ilmu Lingkungan Universitas Padjajaran, 2009), h. 6. 
ahli sejak dua dekade belakangan ini. Bencana banjir, longsor, dan kekeringan yang semakin sering terjadi dan menelan banyak korban jiwa dan harta telah dituduhkan sebagai dampak dari perubahan iklim global. Dampak ini semakin diperparah oleh kerusakan lingkungan yang semakin menjadi-jadi, antara lain oleh sebab pertambahan penduduk yang mengintervensi kawasan hutan lindung, alam tidak lagi bernilai sakral dan dieksploitasi besar-besaran, gaya hidup antroposentrisme semakin berkembang.

Tabel 1. Beberapa Gangguan dan Kerusakan Lingkungan di Indonesia

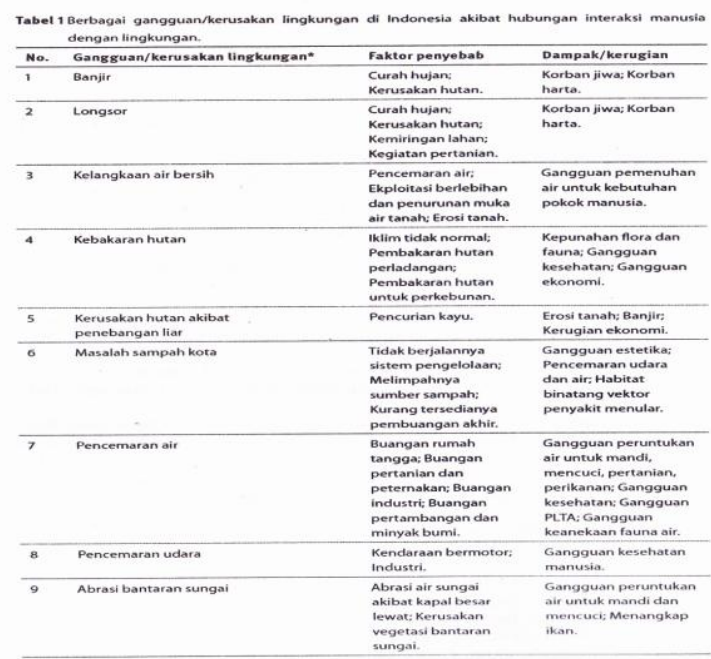

Sumber: Tabulasi dari berbagai sumber media masa ${ }^{29}$

\section{Kondisi Objektif Pencemaran Lingkungan} Danau Maninjau

Aktifitas perikanan yang padat di danau Maninjau ini mengakibatkan pencemaran yang sangat mengkhawatirkan sehingga tekanan terhadap perairan danau semakin meningkat berupa booming fitoplankton, pencemaran dan penurunan kualitas perairan danau yang terus menurun dari waktu ke waktu, bahkan saat ini Danau Maninjau kehilangan hampir separo biota, lebih dari 57 jenis biota, hanya 37 biota

29 Johan Iskandar, Ekologi Manusia dan Pembangunan berkelanjutan..........., h. 8 yang tersisa ${ }^{30}$. Adapun faktor yang paling dominan yang mengakibatkan pencemaran dan kerusakan sumber daya alam lingkungan danau dipengaruhi oleh buangan limbah domestik, perikanan dan pertanian. Berikut data pencemaran akibat limbah di Danau Maninjau:

Tabel 2. Total Limbah Danau Maninjau

\begin{tabular}{|c|c|c|c|}
\hline \multicolumn{4}{|c|}{ Total Limbah P dan N Yang Masuk Da } \\
\hline No & Limbah & $\begin{array}{c}\text { Total Limbah } \\
\text { (ton/tahun) }\end{array}$ & $\%$ \\
\hline 1 & KJA & 393,22 & 94,78 \\
\hline 2 & Penduduk/Permukiman & 7,55 & 1,82 \\
\hline 3 & Pertanian & 5,08 & 1,22 \\
\hline 4 & Deterjen & 9,02 & 2,17 \\
\hline \multicolumn{2}{|r|}{ Total } & 414,87 & 100 \\
\hline
\end{tabular}

Berdasarkan penelitian yang dilakukan oleh Lembaga Penelitian dan Pengembangan (LPP-UM) Universitas Muhammadiyah Sumatera Barat, tingkat pencemaran air dalam bentuk limbah yang masuk ke Danau Maninjau diperkirakan 414,87 ton/pertahun. Data ini menujukkan KJA menyumbang limbah terbesar sekitar $94,5 \%$ dari limbah lainnya sehingga mengakibatkan kematian ikan secara massal.

Tabel 3. Peristiwa Kematian Ikan Masal di Danau Maninjau Pada Periode Tahun 2009 2015

\begin{tabular}{ccc}
\hline No & Waktu & Kerugian \\
\hline 1. & 2-7 Januari 2011 & Rp 150 milyar \\
\hline 2. & 11-12 Maret & Rp 4,8 milyar \\
& 2012 & \\
\hline 3. & $6-7$ November & Rp 24,1 milyar \\
& 2013 & terdiri dari: \\
& & Ikan yang mati \\
& & 1.657 ton
\end{tabular}

\begin{tabular}{ccc}
\hline 4. & 11 Januari 2014 & $\begin{array}{c}\text { Ikan yang mati 200 } \\
\text { ton }\end{array}$ \\
\hline 5 & 15 Juli 2015 & Rp. 134, 3 milyar \\
\hline \multicolumn{2}{c}{ Sumber: Kompas 2015 }
\end{tabular}

${ }^{30}$ Tim Redaksi, "Untuk Penyelamatan Danau Maninjau, Ada Tiga Indikator Yang Harus Dilakukan" diakses dari www.agammediacenter.co.id. pada tanggal 15 April 2016 
Apabila tidak segera dicarikan solusi yang tepat maka akan berdampak kurang baik terhadap penyelamatan danau yang menjadi kebanggaan itu. Sejauh ini Pemkab. Agam sudah melakukan upaya menuju penyelamatan Danau Maninjau melalui beberapa program seperti adanya Gerakan Pembangunan Penyelamatan Salingka Danau Maninjau (Gerbang Pensi), pendataan ulang jumlah keramba, mendatangkan berbagai tim peneliti termasuk dari LIPI dan dunia perguruan tinggi, melakukan sosialisasi, membuat draf peraturan daerah dan lainnya. Namun upaya ini belum maksimal, karena sampai saat ini kondisi lingkungan danau semakin hari semakin memprihatinkan. Hal ini tentu dengan melibatkan semua pihak demi keberhasilan dan pengentasan masalah lingkungan yang sedang dihadapi.

Berdasarkan fenomena kerusakan di atas, dalam skala nasional kesadaran akan pentingnya keterpaduan pengelolaan danau di Indonesia, telah dicapai Kesepakatan 9 Menteri untuk Pengelolaan Danau Berkelanjutan dan Penentuan Danau Prioritas Nasional Tahap I pada saat Konferensi Nasional Danau Indonesia I tahun 2009 di Denpasar, Bali. Kesepakatan ini menjadi momentum untuk merevitalisasi pengelolaan danau di Indonesia, dengan prinsip pengelolaan yaitu keseimbangan ekosistem dan daya dukung lingkungan hidup, serta salah satu kunci keberhasilan yaitu sinkronisasi dan sinergi gerakan para pemangku kepentingan.

Selanjutnya pada Konferensi Nasional Danau Indonesia II tahun 2011 di Semarang, Jawa Tengah, diluncurkan Gerakan Penyelamatan Danau (Germadan) berupa dokumen rencana aksi penyelamatan ekosistem Danau Rawapening, sebagai model rencana aksi penyelamatan danau untuk kemudian direplikasikan terhadap danaudanau prioritas lainnya. Upaya penyelamatan danau di Indonesia dikuatkan oleh terbentuknya Panitia Kerja (Panja) Danau Komisi VII DPR RI Periode 2012-2014, serta tersusunnya Grand Design Penyelamatan Danau Indonesia pada Tahun 2011. Hingga saat ini telah tersusun Germadan (Rencana Aksi Penyelamatan) 15 danau prioritas nasional. Satu di antara danau yang menjadi prioritas nasional itu adalah danau Maninjau.

Tidak cukup dengan itu, memasuki periode pembangunan lima-tahun 2015-2019, telah ditetapkan Rencana Pembangunan Jangka Menengah Nasional (RPJMN) 20152019 yang dengan tegas menyebutkan bahwa salah satu dari sembilan Agenda Pembangunan Nasional adalah mewujudkan partisipasi masyarakat melalui kemandirian ekonomi dengan menggerakkan sektor-sektor strategis. Pada Sub Agenda Prioritas Ketahanan Air disebutkan bahwa salah satu sasaran yang akan dicapai adalah Pemeliharaan dan Pemulihan Sumber Air dan Ekosistem melalui Pengelolaan Terpadu di 15 Danau Prioritas Nasional tahap 2, dengan mengimplementasikan dan melanjutkan Rencana Aksi Penyelamatan Ekosistem Danau dengan menggerakkan partisipasi masyarakat.

Partisipasi Masyarakat dalam Gerakan Penyelamatan Danau Maninjau

Gerakan penyelamatan danau merupakan kegiatan secara nasional untuk menyelematkan danau yang terancam kelestariannya dari bentuk eksploitasi dan pencemaran. Gerakan nasional ini merupakan sinergi dari semua pihak yang dikoordinir oleh pemeritah kabupaten lokasi danau sebagai perpanjang tangan kementerian lingkungan hidup.

Ide pencetusan gerakan ini adalah hasil rekomendasi dari Konferensi Nasional Danau Indonesia (KNDI) I yang dilaksanakan di Denpasar, Bali, 13-15 Agustus 2009 dengan tema Pengelolaan Danau dan Antisipasi Perubahan Iklim menjadi peristiwa penting 
untuk upaya penyelamatan ekosistem danau yang lebih serius. KNDI I ini telah menghasilkan suatu Kesepakatan Bali tentang Pengelolaan Danau Berkelanjutan yang ditandatangani oleh 9 Menteri antara lain Menteri Lingkungan Hidup, Menteri Dalam Negeri, Menteri Pekerjaan Umum, Menteri Kehutanan, Menteri Pertanian, Menteri Kelautan dan Perikanan, Menteri Pariwisata dan Ekonomi Kreatif, Menteri Energi dan Sumber Daya Mineral dan Menteri Riset dan Teknologi. Kesembilan Menteri tersebut telah bersepakat dalam mengelola dan menyelamatkan bersama ekosistem danau prioritas yang terbagi menjadi dua periode yaitu Danau Prioritas I (2009-2014) dan Danau prioritas II (2015-2019) sebagai lanjutan tahap I. Adapun danau yang menjadi prioritas nasional itu adalah yakni Dabau Toba, Maninjau, Singkarak, Kerinci, Rawa Danau, Rawa Pening, Batur, Sentarum, Kaskade Mahakam, Tempe, Tondano, Matako, Poso, Sentani dan Limboto ${ }^{31}$.

Sebagai upaya percepatan pelaksanaan Kesepakatan Bali tahun 2009 tentang Pengelolaan Danau Berkelanjutan, maka pada Konferensi Nasional Danau Indonesia II yang diselenggarakan pada tanggal 13 - 14 Oktober 2011 di Kota Semarang telah diluncurkan Rencana Aksi Penyelamatan Ekosistem Danau Indonesia dengan memilih Danau Rawapening sebagai model Gerakan Penyelamatan Danau (GERMADAN). Terdapat 7 Program Super Prioritas dan 11 Program Prioritas dalam Rencana Aksi dalam penanganan danau Rawapening yang berada dalam kondisi terancam ${ }^{32}$.

Bahkan selanjutnya pihak pemerintah telah menetapkan Grand Design Penyelamatan Ekosistem Danau Indonesia

\footnotetext{
31 Tim Penyusun, Profil 15 Danau Prioritas Nasional......., h. 2.

32 Tim Penyusun, Profil 15 Danau Prioritas Nasional......., h. 2.
}

disusun untuk menjadi acuan bagi para pemangku kepentingan baik pemerintah, dunia usaha maupun masyarakat dalam merencanakan, melaksanakan dan mengevaluasi pelaksanaan penyelamatan ekosistem danau serta menjadi arahan bagi Kementerian/Lembaga/Pemerintah Daerah dalam menyusun Rencana Aksi Penyelamatan Ekosistem Danau ${ }^{33}$.

$$
\text { Penyusunan Grand Design }
$$

penyelamatan ekosistem danau Indonesia dilatarbelakangi adanya upaya-upaya yang dilakukan Kementerian Lingkungan Hidup dengan berbagai pihak untuk menyelamatkan ekosistem danau yang kondisinya semakin mengkhawatirkan sehingga fungsinya sebagai penyangga kehidupan semakin berkurang. Grand Design Penyelamatan Ekosistem Danau Indonesia ini berisikan program dan kegiatan penyelamatan ekosistem danau yang telah terintegrasi dengan peran dan fungsi seluruh sektor terkait. Terdapat 8 (delapan) Program Inti Penyelamatan Danau yaitu; 1) Penataan Ruang Kawasan Danau; 2) Penyelamatan DAS dan DTA Danau; 3) Penyelamatan Ekosistem Lahan Sempadan Danau; 4) Penyelamatan Ekosistem Perairan Danau; 5) Pemanfaatan Sumber Daya Air Danau; 6) Pengembangan Sistem Monitoring, Evaluasi, dan Informasi Ekosistem Danau; 7) Pengembangan Kapasitas, kelembagaan dan Koordinasi; 8) Peningkatan Peran dan Partisipasi Masyarakat ${ }^{34}$.

\section{Kesimpulan}

Penelitian tentang kearifan lokal dan tema-tema lingkungan di atas umumnya meneliti tentang pertanian, hutan lindung dan desa wisata, penulis belum menemukan studi

${ }^{33}$ Kementerian Lingkungan Hidup, Siaran Pers Grand Design Penyelamatan Ekosistem Danau Indonesia, diakses dari www.mnlh.go.id pada tanggal 1 Mei 2016.

${ }^{34}$ Kementerian Lingkungan Hidup, Siaran Pers Grand Design Penyelamatan Ekosistem Danau Indonesia......, h. 2 . 
yang lebih terfokus dalam isu lingkungan dalam penyelamatan danau. Sekalipun ada ketika bicara tenang kearifan lokal akan berbeda fenomena di setiap lokasi dan daerah, karena masing-masing budaya mempunyai keunikan dan perbedaan dalam kontens budaya dan persoalan yang mengitarinya.

Kegiatan yang umumnya di bagian badan perairan danau, berupa pembudidayaan ikan dengan teknik keramba jaring apung (KJA) juga merupakan sumber limbah yang potensial mencemari perairan danau. Saat ini kegiatan perikanan KJA sudah melampaui daya dukung perairan danau. kegiatan budidaya perikanan dengan teknik KJA selalu mengalami peningkatan setiap tahunnya. Sampai akhir tahun 2006 saja, terdapat 8.955 unit KJA yang beroperasi di perairan Danau Maninjau $^{35}$. Bahkan pada tahun 2015 jumlah karamba meningkat tajam sudah sangat melebihi kapasitas yaitu \pm 23.000 unit KJA dari batas toleransi 6.000 unit KJA.

\section{Daftar Pustaka}

\section{Buku Teks}

Abdullah, Irwan, (ed.al), Agama dan Kearifan Lokal dalam Tantangan Zaman (Yogyakarta: Pustaka Pelajar, 2008).

Budiman, Hikmat, (ed.al) Hak Minoritas, Ethnos, Demos dan Batas-batas Multikulturalism (Jakarta: The Interseksi Foundation, 2009).

Endraswara, Suwardi, Metodologi Penelitian Kebudayaan (Yogyakarta: Gadjah Mada University Press, 2006).

Iskandar, Johan, Ekologi Manusia dan Pembangunan berkelanjutan (Bandung: Program Studi Magister Ilmu Lingkungan Universitas Padjajaran, 2009).

${ }_{35}$ Tim Redaksi, "Untuk Penyelamatan Danau Maninjau, Ada Tiga Indikator Yang Harus Dilakukan" diakses dari www.agammediacenter. co.id. pada tanggal 15 April 2016.
Keraf, Sonny, Etika Lingkungan (Jakarta: Kompas, 2002).

Lincoln, Yvonna S. dan E.G Guba., Naturalistic Inquiry (London: Sage Publication 1985).

Moleong, Lexy J., Metode Penelitian Kualitatif (Bandung: PT Rosdakarya, 2009).

Salim Emil, "Kepemimpinan Lingkungan" dalam Arif Budimanta dkk, Enviromental Leadership (Jakarta: ICDS, 2005).

Soemarwoto, Ottoe, Analisis Dampak Lingkungan (Yogyakarta: Gajah Mada University Press, 2003).

Spredley, James, P, Metodologi Etnografi, diterjemahkan oleh M. Zulfa Elizabeth, judul asli, The Etnographic Interview (Yogyakarta: PT Tiara Wacana Yogya, 1997).

Sunaryo dan L. Joshi. Peranan Pengetahuan Ekologi Lokal dalam Sistem Agroforestri. (Bogor: World Agroforestry Centre (ICRAF) Southeast Asia Regional Office Indonesia, 2003).

Tim Penyusun, Profil 15 Danau Prioritas Nasional, Jakarta: Kementerian Lingkungan Hidup RI, 2011).

\section{Jurnal}

Indrawardana, Ira, "Kearifan Lokal Adat Masyarakat Sunda Dalam Hubungan Dengan Lingkungan Alam", Komunitas, Vol. 4, No. 1, 2012.

Lukman, "Pengembangan Karamba Jaring Apung Pertimbangan Dayadukung Dan Ancamannya Terhadap Lingkungan Perairan Danau Maninjau Sumatera Barat", Jurnal Limnotek LIPI, Vol. 2, 2011.

Mukhtar, "Pengelolaan Program Hutan Kemasyarakatan Berbasis Kearifan Lokal: Studi Kasus Di Kawasan Hutan Lindung Sesaot Lombok Barat", Wacana, Vol. 13, No. 1, 2010.

Soeprobowati, Tri Retnaningsih, "Integrated Lake Basin Management For Save 
Indonesian Lake Movement, Procedia Environmental Sciences, Vol. 23, 2015.

Retnowati, Arry, "Environmental Ethics in Local Knowledge Responding to Climate Change: An Understanding of Seasonal Traditional Calendar PranotoMongso and Its Phenology in Karst Area of Gunung Kidul, Yogyakarta, Indonesia", Procedia Environmental Sciences, Vol. 20, 2014.

Sumarmi, "Local Wisdom of Osing People in Conserving Water Resources", Jurnal Komunitas, Vol. 7, No. 1, 2015.

Triyanto, Lukman dan Ami A. Meutia, "Induksi Keramba Jaring Apung Berlapis sebagai Alternatif Sistem Pemeliharaan Ikan dalam Keramba Ramah Lingkungan di Danau Maninjau Sumatera Barat", Jurnal Limnotek LIPI, Vol. 2, 2005.

Vitasurya, Vincentia Reni, "Local Wisdom for Sustainable Development of Rural Tourism, Case on Kalibiru and Lopati Village, Province of Daerah Istimewa Yogyakarta". Procedia-Social and Behavioral Sciences, Vol. 216, 2016.

\section{Artikel Media}

Kementerian Lingkungan Hidup, Siaran Pers Grand Design Penyelamatan Ekosistem Danau Indonesia, diakses dari www.mnlh.go.id pada tanggal 1 Mei 2016

Tim Redaksi, "Untuk Penyelamatan Danau Maninjau, Ada Tiga Indikator Yang Harus Dilakukan" diakses dari www.agammediacenter. co.id. pada tanggal 15 April 2016.

Tim Padang Ekspres, "Penyelamatan Danau Maninjau Dimulai Penyelamatan Danau Maninjau Dimulai”, Padang Ekspres 18 March 2016. 